\title{
AT, expression in human urethral stricture tissue
}

This article was published in the following Dove Press journal:

Research and Reports in Urology

12 September 2017

Number of times this article has been viewed

\section{Safendra Siregar' \\ Aga Parardya' \\ Jupiter Sibarani' \\ Tjahjodjati Romdan' \\ Kuncoro Adi' \\ Bethy S Hernowo 2 \\ Anglita Yantisetiasti ${ }^{2}$ \\ 'Department of Urology, ${ }^{2}$ Department of Pathological Anatomy, Hasan Sadikin Hospital, Faculty of Medicine University of Padjadjaran, Bandung, Indonesia}

Background: Urethral stricture has a high recurrence rate. There is a common doctrine stating that "once a stricture, always a stricture". This fibrotic disease pathophysiology, pathologically characterized by excessive production, deposition and contraction of extracellular matrix is unknown. Angiotensin II type 1 ( $\mathrm{AT}_{1}$ ) receptor primarily induces angiogenesis, cellular proliferation and inflammatory responses. $\mathrm{AT}_{1}$ receptors are also expressed in the fibroblasts of hypertrophic scars, whereas angiotensin II (AngII) regulates DNA synthesis in hypertrophic scar fibroblasts through a negative cross talk between $\mathrm{AT}_{1}$ and angiotensin II type 2 ( $\mathrm{AT}_{2}$ ) receptors, which might contribute to the formation and maturation of human hypertrophic scars.

Objective: This study was conducted to determine the expression of $\mathrm{AT}_{1}$ receptors in urethral stricture tissues.

Methods: Urethral stricture tissues were collected from patients during anastomotic urethroplasty surgery. There were 24 tissue samples collected in this study with 2 samples of normal urethra for the control group. Immunohistochemistry study was performed to detect the presence of $\mathrm{AT}_{1}$ receptor expression. Data were analyzed using Mann-Whitney $U$ test, and statistical analysis was performed with SPSS version 20.

Results: This study showed that positive staining of $\mathrm{AT}_{1}$ receptor was found in all urethral stricture tissues $(n=24)$. A total of $8.33 \%$ patients had low intensity, $41.67 \%$ had moderate intensity and $50 \%$ had high intensity of $\mathrm{AT}_{1}$ receptors, while in the control group, $100 \%$ patients had no intensity of $\mathrm{AT}_{1}$ receptors. Using the Mann-Whitney $U$ test, it was found that urethral stricture tissue had a higher intensity of $\mathrm{AT}_{1}$ receptors than normal urethral tissue with a $p$-value $=0.012$. Conclusion: The results showed that $\mathrm{AT}_{1}$ receptor had a higher intensity in the urethral stricture tissue and that $\mathrm{AT}_{1}$ receptor may play an important role in the development of urethral stricture. Keywords: angiotensin, $\mathrm{AT}_{1}$ receptor, urethral stricture

\section{Introduction}

Urethral stricture is defined as a narrowing of a segment of urethra that is enveloped by corpus spongiosum and specifically underwent spongiofibrosis process. Accumulation of fibrotic tissue will eventually lead to disturbance of voiding process and consequently affect the quality of life. The etiology of urethral stricture disease is traumatic, inflammatory, iatrogenic and idiopathic (Table 1). Every process that causes injury of urethral epithelium or corpus spongiosum could eventually lead to urethral stricture disease. ${ }^{1}$

Until now, urethral stricture disease is still a challenging problem, and its management has been still developing. From 16th century until now, the methods for overcoming urethral stricture have constantly changed from metal dilator, blind inter-
Correspondence: Safendra Siregar Sekretariat Urologi, Hasan Sadikin Hospital, Jalan Pasteur No 38, Bandung,

West Java, Indonesia

$\mathrm{Tel}+6281 \quad 1232827$

Email safendra_sir@yahoo.co.id 
Table I AT, receptor expression in urethral tissue

\begin{tabular}{llll}
\hline $\mathbf{A T}$, expression & Urethral stricture & Normal urethra & p-value \\
\hline$(-)$ negative & $0(0.0 \%)$ & $2(100.0 \%)$ & 0.012 \\
$(+)$ mild & $2(8.33 \%)$ & $0(0.0 \%)$ & \\
$(+)$ moderate & $10(41.67 \%)$ & $0(0.0 \%)$ & \\
$(+)$ strong & $12(50.0 \%)$ & $0(0.0 \%)$ & \\
\hline
\end{tabular}

Abbreviation: $\mathrm{AT}_{\mathrm{I}}$, angiotensin II type I.

nal urethrotome in the 18th century, direct vision internal urethrotomy (DVIU) to urethroplasty surgery now. ${ }^{2}$

One challenging problem of the urethral stricture is its high recurrence rate. There is a common doctrine stating that "once a stricture, always a stricture". A study by Zehri et al ${ }^{3}$ in 2009 revealed that the median duration between optical urethrotomy and recurrence was 4.5 months and the recurrence rate was $34 \%$.

Another study by Han et al in 2015 found that $26 \%$ of all patients had a recurrence at a mean follow-up of 62 months. The recurrence rate after anastomotic urethroplasty was $18 \%$, compared with $31 \%$ after substitution urethroplasty. The mean time to recurrence was 34 months. ${ }^{4}$

The mechanism of this fibrotic disease, pathologically characterized by excessive production, deposition and contraction of extracellular matrix, is still unclear. Recent studies showed the role of renin-angiotensin system (RAS) in fibroblast proliferation and extracellular matrix deposition. Shirazi et $\mathrm{al}^{5}$ in 2007 showed a decrease in urethral stricture recurrence after DVIU using intraurethral captopril gel compared to the placebo group.

Another study by Nababan et al (unpublished, 2013) observed an increasing expression of angiotensin II (AngII) receptor in injured urethra of Wistar mice.

All the study mentioned earlier showed us that RAS may have a role in urethral stricture formation and recurrence. To demonstrate the relationship of RAS with urethral stricture formation in human beings, we conducted this study.

\section{Methods}

\section{Tissue samples}

Tissue samples were obtained from urethral stricture segment that had been excised from the patients during anastomotic urethroplasty surgery for patients with anterior urethral stricture. The segment that was excised should also contain normal urethral tissue. In total, we obtained 24 urethral tissue samples from patients with urethral stricture and 2 normal urethra from cadaveric bodies. The urethral stricture tissue samples were obtained under written informed consent from the 24 patients who underwent anastomotic urethroplasty pro- cedure for research purpose. This study was approved by the ethical committee of Hasan Sadikin Hospital, Bandung. The normal urethra tissue samples were obtained from cadaveric tissues that had deceased less than 24 hours. The cadaveric tissues were also obtained for education and research purpose and had been approved by the ethical committee of Hasan Sadikin Hospital, Bandung, and Department of Forensic Medicine of Hasan Sadikin Hospital, Bandung.

\section{Immunohistochemical staining of Angll type I}

Immunohistochemistry (IHC) examination was done using angiotensin II type 1 ( $\mathrm{AT}_{1}$ ) with 100 times dilution and ultra vision/HRP system with three-step anti-polyvalent detection system conjugated with secondary antibody.

The tissue samples were fixed with $10 \%$ formalin and embedded in paraffin. The samples then were cut as thick as $4-5 \mu \mathrm{m}$ using microtome and stored in a $38-40^{\circ} \mathrm{C}$ incubator. Sections then were deparaffinized with xylol and sequentially rehydrated in a graded ethanol series for $5 \mathrm{~min}$ each.

The sections were dipped inside $90 \%, 80 \%$ and $70 \%$ alcohol solution and then washed using Aquadest and dipped inside boiled buffer citrate solution for 5 minutes and cooled at room temperature. After that, the sections were washed using phosphate-buffered saline (PBS) for 3 times, 5 minutes each. Blocking serum was added, and the sections were then incubated in a closed room for 10 minutes and washed using PBS for 3 times, 5 minutes each.

AngII was added to the sections, and the sections were then incubated in room temperature for 60 minutes and washed using PBS for 3 times, 5 minutes each. Biotinylated universal secondary antibody was added to the sections and then incubated in a closed room for 10 minutes and washed using PBS for 3 times, 5 minutes each. After that, diaminobenzylene chromogenic solution was added, incubated in the closed room for 5 minutes and washed using running water for 5 minutes. Counterstaining was done using Mayer's hematoxylin, incubated for 2 minutes and then washed using running water.

Sequential dehydration was done by dipping the sections in 70\%, 80\% and $90 \%$ alcohol solutions for 5 minutes each and $100 \%$ ethanol solution for 2 times, 5 minutes each. The sections were then dried using filter paper, dipped into xylol for 3 minutes and observed and analyzed using light microscope.

$\mathrm{AT}_{1}$ receptor expression measurement procedure was done in Pathological Anatomy Department's laboratory, Hasan Sadikin Hospital, Bandung. All sections were exam- 
ined by experts in pathology. $\mathrm{AT}_{1}$ expression was measured by observing immunoexpression in the fibrotic tissue of the urethra.

\section{Statistical analysis}

To determine the expression of $\mathrm{AT}_{1}$ in urethral stricture tissue compared to normal urethral tissue, we used Mann-Whitney $U$ test with $95 \%$ confidence level ( $\alpha=5 \%)$. Statistical analysis was performed using SPSS version 20.0.

\section{Result of the study}

Descriptive analysis was done to $\mathrm{d}$

etermine the $\mathrm{AT}_{1}$ receptor in urethral stricture tissue compared to normal urethral tissue. The $\mathrm{AT}_{1}$ expression was graded as negative, mild positive, moderate positive and strong positive (Figure 1).

From a total of 24 samples of urethral stricture tissues, $2(8.33 \%)$ samples were categorized as mild positive, 10 (41.67\%) samples were categorized as moderate positive, and $12(50 \%)$ samples were categorized as strong positive. None of the samples were categorized as negative. From the normal urethra group, none of the samples expressed the $\mathrm{AT}_{1}$ receptor in their tissues.

Using Mann-Whitney $U$ test, we concluded that $\mathrm{AT}_{1}$ receptor expression in urethral stricture tissue was significantly higher than normal urethral tissue ( $p=0.012$; Table 1$)$.

\section{Discussion}

Urethral stricture disease is a fibrotic condition of a segment of urethra due to spongiofibrotic process of the urethra and corpus spongiosum (Figures 2 and 3). Damage to urethral epithelium or corpus spongiosum would eventually lead to urethral stricture formation. Pathological process in urethral stricture formation showed a change in pseudostratified columnar epithelium that lines the urethra toward squamous metaplastic epithelium. ${ }^{7}$ Further damage to the metaplastic region can cause urine extravasation that leads to fibrotic process of the corpus spongiosum. This process will lead to narrowing of the urethral caliber and cause one to develop lower urinary tract symptoms and eventually urinary retention.

Baskin et al in 1993 showed us that there were no differences in the amount of collagens in urethral stricture tissue compared to that in normal urethra, but they have found a change in the ratio between collagen types that could explain the fibrotic and scar formation process. In corpus spongiosum of normal urethral tissue, the ratio between collagen type I and type III was $75 \%: 25 \%$, whereas in urethral stricture tissue, the ratio was $16 \%: 84 \% .^{6}$

RAS is an endocrine system cascade, which consists of angiotensinogen ( $\alpha$-glycoprotein), that is released from the liver into the circulation and transformed by renin, which is produced by the juxtaglomerular apparatus of the kidney, into angiotensin I (AngI). AngI will further transform
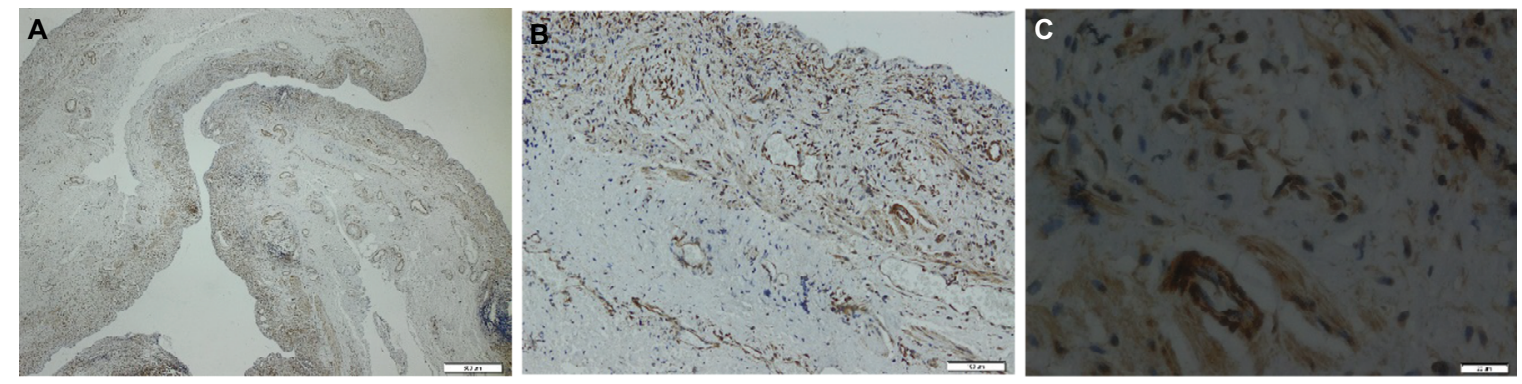

Figure I AT, expression in urethral stricture tissue: (A) mild positive, (B) moderate positive and (C) strong positive.

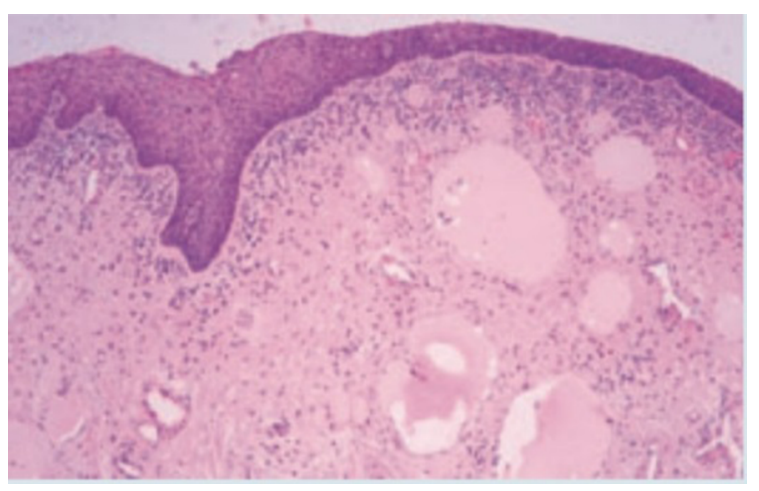

Figure 2 Normal urethral tissue (100× magnification).

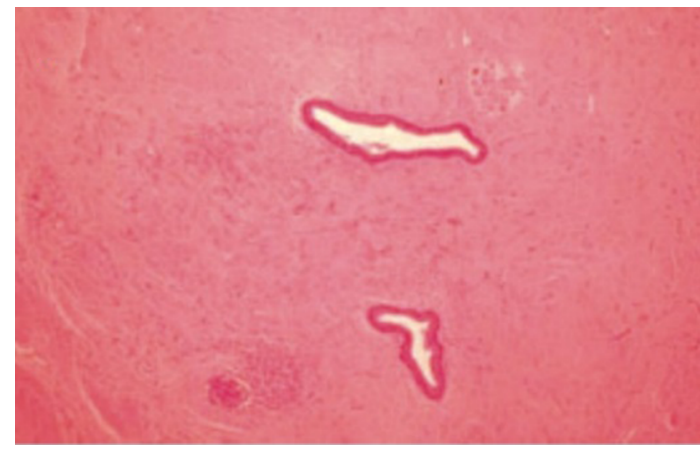

Figure 3 Urethral stricture tissue (100× magnification). 
into more potent AngII by angiotensin-converting enzyme (ACE; Figure 4). AngII is the potent form that produces vasoconstriction of vascular wall or stimulates androgen production from adrenal cortex through angiotensin receptor. ${ }^{7-11}$

\section{Angll receptor}

AngII has 2 kind of receptors, AT $_{1}$ receptor and angiotensin II type $2\left(\mathrm{AT}_{2}\right)$ receptor. $\mathrm{AT}_{1}$ is a $\mathrm{G}$ protein receptor that mediates several cascades, including phospholipase A, C and $\mathrm{D}$ activation, adenylate cyclase inhibition, tyrosine phosphorylation mediation and mediation of second messenger transduction, such as MAP kinase and phosphatidylinositol 3-kinase (PI3K). ${ }^{10}$ Most of $\mathrm{AT}_{1}$ mediate physiologic and pathophysiologic processes, including growth factors, vasoconstriction, aldosterone secretion and sympathetic outflow (Figure 5). ${ }^{13-17}$

The $\mathrm{AT}_{1}$ distribution and location in the tissues have been widely studied on human tissues or animal studies. Dominantly, $\mathrm{AT}_{1}$ has been found in the brain, adrenal glands, blood vessels and kidneys. ${ }^{12,18,19,20}$
Recent studies stated that there is expression of $\mathrm{AT}_{1}$ in human prostate, which is concentrated in the periurethral area and stromal tissue. This finding showed that AngII has its role in cellular growth and sympathetic activity of the prostate and is related to voiding stream. ${ }^{21}$

AngII stimulates the $\mathrm{AT}_{1}$ receptor in blood vessels that cause vasoconstriction. It also causes an increase in systemic vascular resistance. $\mathrm{AT}_{1}$ receptor in cardiac cells was known for its chronotropic and inotropic functions. AngII was also known to stimulate proliferation of cardiac cells and fibroblasts and has role in the formation of various growth factors such as fibroblast growth factor, transforming growth factor and platelet growth factor.

$\mathrm{AT}_{2}$ receptor is $30 \%$ homologous with $\mathrm{AT}_{1}$ receptor, even though its relation with $\mathrm{G}$ protein is still controversial. The most common $\mathrm{AT}_{2}$ expression was found in fetal tissue, and it downregulated after birth. $\mathrm{AT}_{2}$ receptor was believed to have a counterregulatory mechanism to protect kidney from damage that was caused by AngII. ${ }^{13,14,16,17,22,23}$

Some clinical studies have showed the nonhemodynamic effects of RAS. ${ }^{23}$ The involvement of AngII in fibrosis forma-

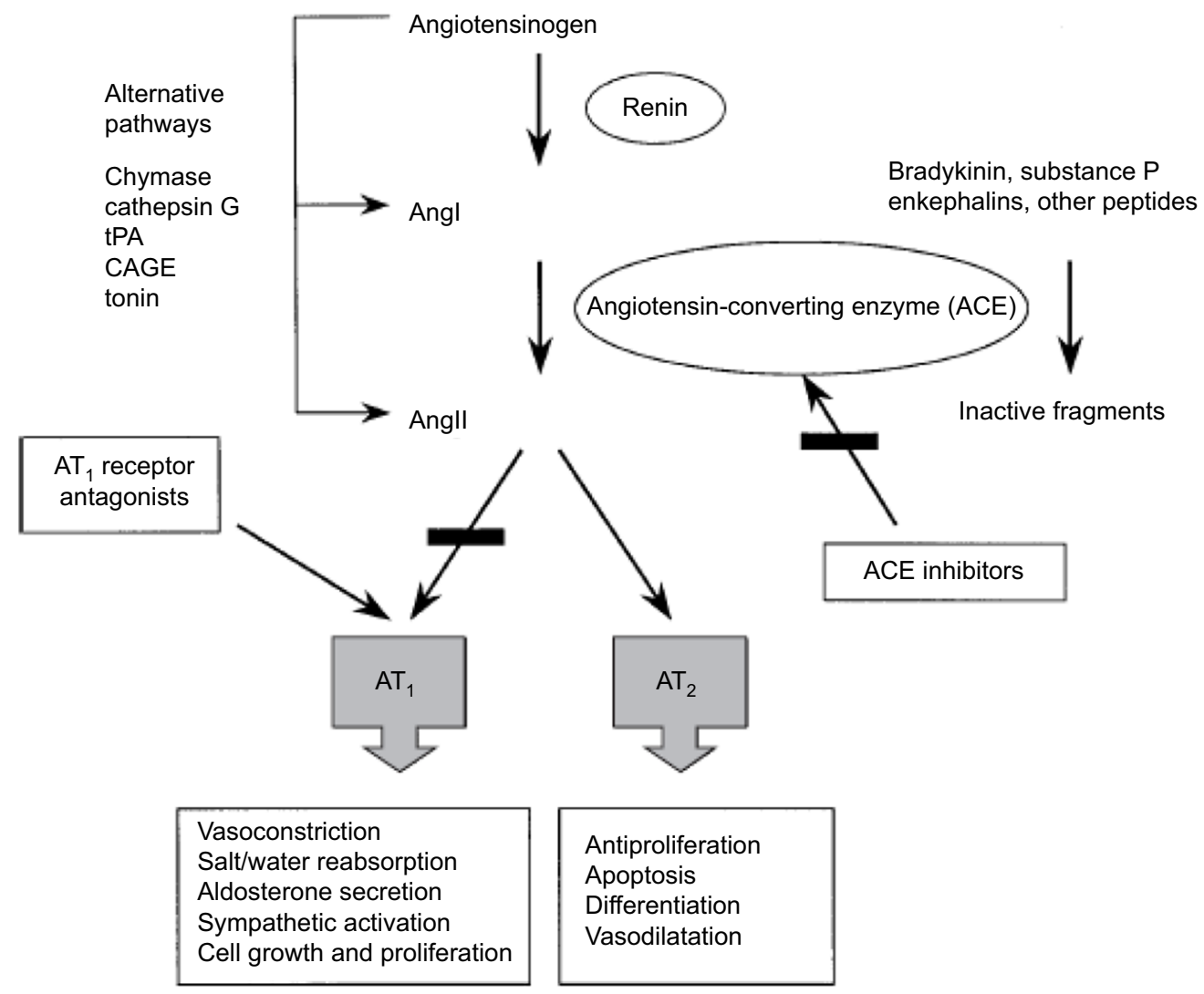

Figure 4 The RAS cascade.

Notes: ACE will convert Angl to more potent Angll. The AT, receptor in tissues has a role in modulation of vasoconstriction, sympathetic activation and including cell growth and proliferation.

Abbreviations: RAS, renin-angiotensin system; Angl, angiotensin I; Angll, angiotensin II; $\mathrm{AT}_{1}$, angiotensin II type I; $A T_{2}$, angiotensin II type 2; ACE, angiotensin converting enzyme; CAGE, chymostatin-sensitive angiotensin II converting enzyme; tPA, tissue plasminogen activator. 


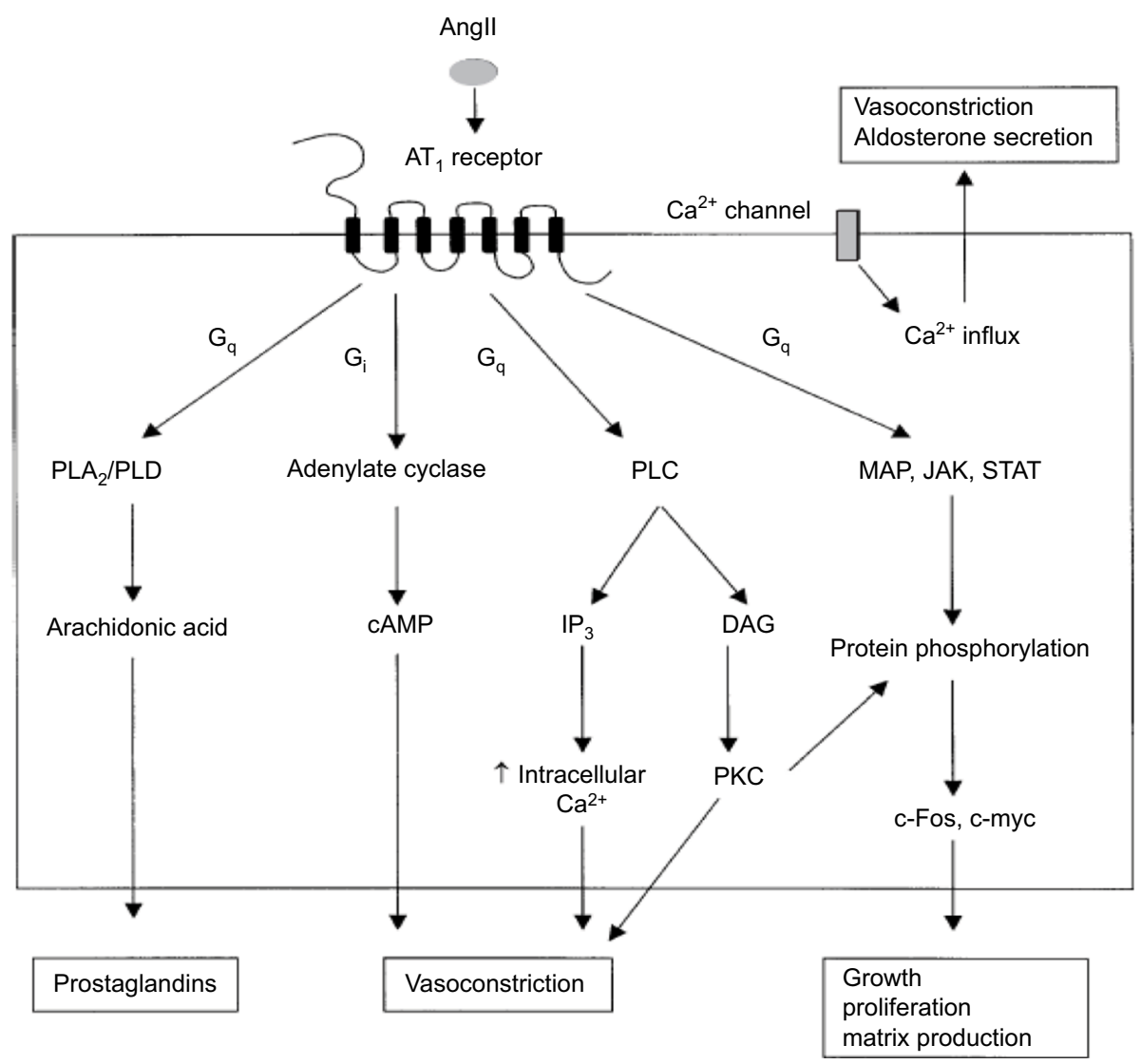

Figure 5 Signal transduction mechanism of AT, receptor.

Note: Angll through MAP, JAK and STAT pathway stimulates tissue growth, cell proliferation and extracellular matrix deposition.

Abbreviations: AT, angiotensin II type I; Angll, angiotensin II; JAK, Janus kinase; STAT, signal transducer and activator of transcription; DAG, diacyl glycerol; cAMP, cyclic adenosine mono phosphate; PLC, phospholipase C.

tion process was seen with the overexpression of renin and angiotensinogen which synergically induce extracellular matrix formation. AngII induces collagen and fibronectin expression. ${ }^{24}$ AngII also increases the proliferation of fibroblast and induces TGF- $\beta_{1}$ expression. ${ }^{25,26}$ Connective tissue growth factor (CTGF) presented as profibrotic cytokine and functioned as an important mediator of TGF- $\beta_{1}$ and as a profibrotic component that stimulates proliferation and activation of fibroblast and induces epithelial cell transition to become fibroblast. ${ }^{27}$

In some other studies, there were a decrease in CTGF expression and fibrotic process in samples that give ACE inhibitor and $\mathrm{AT}_{1}$ blockers. Beside overexpression of extracellular matrix, disturbance of extracellular matrix degradation also leads to fibrosis process. ${ }^{28}$ AngII induces fibrosis not only by increasing extracellular matrix synthesis but also by decreasing the turnover of extracellular matrix. AngII, through $\mathrm{AT}_{1}$ receptor, induces PAI-1 and tissue inhibitor of matrix metalloproteinase-1 (TIMP-1) to inhibit metalloproteinase to slow the degradation of extracellular matrix and produce fibrosis. ${ }^{28}$
In this study, we found a significant difference in $\mathrm{AT}_{1}$ expression between urethral stricture tissue and normal urethra tissue. Despite some limitations in this study, such as lack of tissue samples and inequality between urethral stricture sample and normal urethra group, this study showed us another insight of fibrotic formation in urethral tissue and the probability of $\mathrm{AT}_{1}$ receptor involvement in fibrosis formation in human urethral tissue.

\section{Study limitation}

The cadaveric urethral tissue in this study was taken from the dead body less than 24 hours and was fixated using formaldehyde. We recognize the limitation of this sample that decomposing process might affect the $\mathrm{AT}_{1}$ expression in the urethral tissue. However, normal urethral tissue was impossible to collect unless we used cadaveric tissue. We excluded cadaver that decreased caused by urogenital cause, trauma or other conditions that may affect the urethra and collected the urethral tissue as soon as possible after the permission was granted from the ethical committee. 


\section{Disclosure}

The authors report no conflicts of interest in this work.

\section{References}

1. Stein MJ, DeSouza RA. Anterior urethral stricture review. Transl Androl Urol. 2013;2(1):32-38.

2. Smith TG. Current management of urethral stricture disease. Indian $J$ Urol. 2016;32(1):27-33.

3. Zehri AA, Ather MH, Afshan Q. Predictors of recurrence of urethral stricture disease following optical urethrotomy. Int $J$ Surg. 2009;7(4):361-364.

4. Han JS, Liu J, Hofer MD, et al. Risk of urethral stricture recurrence increases over time after urethroplasty. Int J Urol. 2015;22(7):695-699.

5. Shirazi M, Khezri A, Samani SM, Monabbati A, Kojoori J, Hassanpour A. Effect of intraurethral captopril gel on the recurrence of urethral stricture after direct vision internal urethrotomy: phase II clinical trial. Int J Urol. 2007;14(3):203-208.

6. Baskin LS, Constantinescu SC, Howard PS, et al. Biochemical characterization and quantitation of the collagenous components of urethral stricture tissue. J Urol. 1993;150(2 pt 2):642-647.

7. Deschepper CF. Angiotensinogen: hormonal regulation and relative importance in the generation of angiotensin II. Kidney Int. 1994;46(6):1561-1563.

8. Hall JE. Historical perspective of the renin-angiotensin system. Mol Biotechnol. 2003;24(1):27-39.

9. Menard J, Bouhnik J, Clauser E, Richoux JP, Corvol P. Biochemistry and regulation of angiotensinogen. Clin Exp Hypertens. 1983;5(7-8):1005-1019.

10. Hackenthal E, Paul M, Ganten D, Taugner R. Morphology, physiology, and molecular biology of renin secretion. Physiol Rev. 1990;70(4):1067-1116.

11. de Gasparo M, Catt KJ, Inagami T, Wright JW, Unger T. International union of pharmacology. XXIII. The angiotensin II receptors. Pharmacol Rev. 2000;52(3):415-472.

12. Kohlstedt K, Brandes RP, Muller-Esterl W, Busse R, Fleming I. Angiotensin-converting enzyme is involved in outside-in signaling in endothelial cells. Circ Res. 2004;94(1):60-67.

13. Kaschina E, Unger T. Angiotensin AT1/AT2 receptors: regulation, signalling and function. Blood Press. 2003;12(2):70-88.

14. Unger $\mathrm{T}$. The angiotensin type 2 receptor: variations on an enigmatic theme. J Hypertens. 1999;17:1775-1786.
15. Unger T, Chung O, Csikos T, et al. Angiotensin receptors. J Hypertens Suppl. 1996;14(5):S95-S103.

16. Timmermans PB, Wong PC, Chiu AT, et al. Angiotensin II receptors and angiotensin II receptor antagonists. Pharmacol Rev. 1993;45(2): 205-251.

17. Stoll M, Steckelings UM, Paul M, Bottari SP, Metzger R, Unger T. The angiotensin AT2-receptor mediates inhibition of cell proliferation in coronary endothelial cells. J Clin Invest. 1995;95(2):651-657.

18. Ferrario CM, Chappell MC. Novel angiotensin peptides. Cell Mol Life Sci. 2004;61(21):2720-2727.

19. Kohlstedt K, Busse R, Fleming I. Signaling via the angiotensinconverting enzyme enhances the expression of cyclooxygenase- 2 in endothelial cells. Hypertension. 2005;45(1):126-132.

20. Kohlstedt K, Shoghi F, Muller-Esterl W, Busse R, Fleming L. CK2 phosphorylates the angiotensin-converting enzyme and regulates its retention in the endothelial cell plasma membrane. Circ Res. 2002;91(8):749-756.

21. Dinh DT, Frauman AG, Somers GR, et al. Evidence for activation of the renin-angiotensin system in the human prostate: increased angiotensin II and reduced AT(1) receptor expression in benign prostatic hyperplasia. $J$ Pathol. 2002;196(2):213-219.

22. Unger T, Chung O, Csikos T, et al. Angiotensin receptors. J Hypertens Suppl. 1996;14(5):S95-S103.

23. Kobori H, Nangaku M, Navar LG, Nishiyama A. The intrarenal reninangiotensin system: from physiology to the pathobiology of hypertension and kidney disease. Pharmacol Rev. 2007;59(3):251-287.

24. Wolf G. Renal injury due to renin-angiotensin-aldosterone system activation of the transforming growth factor-beta pathway. Kidney Int. 2006;70(11):1914-1919.

25. Zhang C, Meng X, Zhu Z, Liu J, Deng A. Connective tissue growth factor regulates the key events in tubular epithelial to myofibroblast transition in vitro. Cell Biol Int. 2004;28(12):863-873.

26. Ruiz-Ortega M, Ruperez M, Esteban V, et al. Angiotensin II: a key factor in the inflammatory and fibrotic response in kidney diseases. Nephrol Dial Transplant. 2006;21(1):16-20.

27. Zhang C, Meng X, Zhu Z, Yang X, Deng A. Role of connective tissue growth factor in renal tubular epithelial-myofibroblast transdifferentiation and extracellular matrix accumulation in vitro. Life Sci. 2004; 75(3):367-379.

28. Iwano M, Plieth D, DanoffTM, Xue C, Okada H, Neilson EG. Evidence that fibroblasts derive from epithelium during tissue fibrosis. $J$ Clin Invest. 2002;110(3):341-350.
Research and Reports in Urology

\section{Publish your work in this journal}

Research and Reports in Urology is an international, peer-reviewed, open access journal publishing original research, reports, editorials, reviews and commentaries on all aspects of adult and pediatric urology in the clinic and laboratory including the following topics: Pathology, pathophysiology of urological disease; Investigation and treatment of

\section{Dovepress}

urological disease; Pharmacology of drugs used for the treatment of urological disease. The manuscript management system is completely online and includes a very quick and fair peer-review system, which is all easy to use. Visit http://www.dovepress.com/testimonials.php to read real quotes from published authors. 